\title{
PENGARUH LABA AKUNTANSI, TOTAL ARUS KAS, DAN NET PROFIT MARGIN TERHADAP RETURN SAHAM PADA PERUSAHAAN OTOMOTIF YANG TERDAFTAR DI BURSA EFEK INDONESIA
}

\author{
Linda A. Razak ${ }^{1}$, Rahmi Syafitri ${ }^{2}$ \\ ${ }^{1}$ Dosen Universitas Muhammadiyah Makassar \\ 2Dosen Universitas Tadulako, Palu
}

\begin{abstract}
This study aims to determine whether accounting profit, total cash flow and Net Profit Margin effect on Return Shares in Automotive Companies listed on the Indonesia Stock Exchange. The population in this study are all automotive companies listing period 2013 - 2016. Sample taken based on certain criteria or purposive sampling. Data analysis techniques use multiple linear regression. The results show that overall from the period of 2013 to 2016 Accounting profit does not have a significant effect on stock returns due to transitory events in accounting so as not used as a reference by investors to invest, Total cash flow does not have a partial significant influence on stock return because the total cash flow is not enough to have information to be a benchmark to predict stock returns. Net profit margin has a partially significant influence on stock return because the profits generated by the company from the level of sales is also greater then it will attract investors.
\end{abstract}

Keywords: Accounting Profit, Total Cash Flow, Net Profit Margin, Automotive Company

\section{ABSTRAK}

Penelitian ini bertujuan untuk mengetahui apakah laba akuntansi, total arus kas dan Net Profit Margin berpengaruh Terhadap Return Saham pada Perusahaan Otomotif yang terdaftar di Bursa Efek Indonesia. Populasi dalam penelitian ini adalah semua perusahaan otomotif yang listing periode tahun 2013 - 2016. Sampel diambil berdasarkan kriteria tertentu atau purposive sampling. Teknik analisis data menggunakan regresi linier berganda. Hasil penelitian menunjukkan bahwa secara keseluruhan dari periode tahun 2013 sampai tahun 2016 Laba akuntansi tidak mempunyai pengaruh signifikan terhadap return saham karena adanya peristiwa transitory dalam akuntansi sehingga tidak dijadikan sebagai acuan oleh investor untuk berinvestasi, Total arus kas tidak mempunyai pengaruh signifikan secara parsial terhadap return saham karena total arus kas tidak cukup memiliki informasi untuk menjadi tolak ukur memprediksi return saham. Net profit margin mempunyai pengaruh signifikan secara parsial terhadap return saham karena laba yang dihasilkan perusahaan tersebut dari tingkat penjualan juga semakin besar maka akan menarik minat para investor.

Kata kunci: Laba Akuntansi, Total Arus Kas, Net Profit Margin, Perusahaan Otomotif

Jurnal Akun Nabelo: Jurnal Akuntansi Netral, Akuntabel, Objektif Volume 1/Nomor 1/Juli 2018 Jurusan Akuntansi FE-Universitas Tadulako

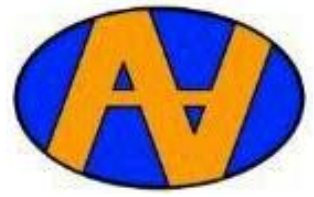




\section{A. PEndahuluan}

Kegiatan investasi atau pemberian pinjaman pada suatu perusahaan dapat dilakukan dengan adanya dasar yang kuat berupa informasi publik. Informasiinformasi tersebut harus memberikan jaminan akan rasa aman bagi para investor dan kreditor akan dana yang mereka salurkan. Informasi-informasi tersebut harus menggambarkan secara akurat kegiatan ekonomi yang dilakukan perusahaan khususnya dalam memperoleh laba. Informasi publik tersebut digunakan oleh investor atau kreditor dengan tujuan untuk memberikan keyakinan bahwa investor akan memperoleh return atas investasi yang dilakukan serta pengembalian atas kredit yang diberikan.

Pada umumnya, terdapat tiga kelompok yang berkepentingan terhadap informasi-informasi tersebut yaitu para pemegang saham dan calon pemegang saham, kreditor dan calon kreditor, serta manajemen perusahaan itu sendiri. Para pemegang saham dan calon pemegang saham menaruh perhatian utama pada tingkat laba perusahaan, baik tingkat laba sekarang maupun kemungkinannya pada masa yang akan datang. Hal ini sangat penting bagi para pemegang saham dan calon pemegang saham karena tingkat laba ini akan mempengaruhi hargaharga saham yang dimiliki.

Tingkat laba ini akan memberikan gambaran mengenai kinerja perusahaan serta untuk menilai kelanjutan hidup perusahaan serta proyeksi terhadap distribusi income atau laba pada masa-masa yang akan datang. Para kreditor pada umumnya berkepentingan terhadap kemampuan perusahaan dalam membayar kewajiban-kewajiban finansial baik jangka pendek maupun jangka panjangnya. Kreditor yang memberikan pinjaman pada perusahaan ingin mendapatkan jaminan bahwa perusahaan tempat mereka menanamkan modalnya akan mampu membayar bunga dan pinjaman pokok tepat pada waktunya. Sedangkan, calon kreditor lebih menekankan pada struktur finansial dan struktur modal perusahaan. Faktor lain yang juga penting bagi kreditor adalah apakah perusahaan tersebut cukup sehat dan bisa diperkirakan akan tetap mencapai kesuksesan pada masa-masa selanjutnya.

Kelompok ketiga yang berkepentingan yaitu manajemen perusahaan sendiri. Manajemen perusahaan memiliki tanggung jawab terhadap kegiatan-kegiatan ekonomi yang dilakukan perusahaan. Informasi tersebut digunakan sebagai dasar untuk mempertahankan dan meningkatkan segala kelebihan yang dimiliki perusahaan serta sebagai acuan untuk melakukan tindakan perbaikan atas kekurangan dan kesalahan yang telah dilakukan.

Ada tiga ukuran kinerja akuntansi suatu perusahaan yaitu: laba akuntansi, arus kas, dan Net Profit Margin (NPM). Informasiinformasi yang terkandung dalam laba akuntansi, arus kas, dan rasio Net Profit Margin (NPM) dapat digunakan oleh investor dan kreditor dalam mengukur kinerja dan meramalkan posisi keuangan suatu perusahaan di masa depan. Keputusan untuk menggunakan salah satu alat ukur tersebut oleh investor dan kreditor ditentukan oleh seberapa besar pengaruh ketiga faktor tersebut terhadap return saham. Semakin besar pengaruhnya terhadap return saham maka semakin akurat penggunaan alat ukur tersebut digunakan untuk menilai kinerja suatu perusahaan.

Laba merupakan salah satu elemen laporan keuangan yang memiliki kandungan informasi lebih tinggi. Laba sering dijadikan sumber untuk mengukur kinerja perusahaan. Laba merupakan kenaikan manfaat ekonomi selama satu periode akuntansi dalam bentuk pemasukan, perubahan aset 
atau penurunan kewajiban yang menyebabkan kenaikan ekuitas yang tidak berasal dari kontribusi penambahan modal. Informasi laba dapat digunakan untuk memprediksi laba di masa mendatang serta memperkirakan resiko investasi maupun kredit. Oleh karena itu, informasi laba sebagai indikator kinerja suatu perusahaan merupakan fokus utama dari pelaporan keuangan saat ini (Rahmawati, 2005).

Data arus kas dianggap menyajikan informasi utama dalam mengevaluasi harga pasar suratsurat berharga (Hendriksen, 1997). Arus kas memiliki arti penting dalam mengevaluasi harga pasar saham karena menggambarkan daya beli umum dan dapat dipindahkan segera dalam perekonomian pasar kepada perorangan maupun organisasi untuk kepentingan tertentu. Arus kas sering kali digunakan investor untuk menganalisis investasi. Data arus kas menunjukkan bagaimana kemampuan perusahaan dalam menghasilkan kas.

Net profit margin digunakan untuk menghitung kemampuan sebuah perusahaan sejauh mana perusahaan tersebut menghasilkan laba yang tinggi pada tingkat penjualan tertentu (Hanafi, 2014). Apabila sebuah perusahaan dapat menghasilkan net profit margin (NPM) yang tinggi maka sebuah perusahaan tersebut dapat dikatakan memiliki kinerja yang baik dan perusahaan yang produktif. Maka dengan adanya peningkatan dari net profit margin maka akan mempengaruhi tingginya tingkat pengembalian return saham pada pihak investor.

Penelitian ini merupakan penelitian lanjutan dari penelitianpenelitian sebelumnya. Beberapa penelitian sebelumnya menunjukkan hasil yang berbeda. Oleh karena itu, penulis tertarik untuk melakukan generalisasi terhadap penelitian sebelumnya dengan mengambil sampel penelitian pada perusahaan otomotif yang terdaftar di Bursa Efek
Indonesia. Pemilihan perusahaan otomotif dilandasi oleh mulai berkembangnya industri otomotif Indonesia. Melihat kondisi industri otomotif yang demikian, penulis tertarik untuk mengetahui dan mengungkap bagaimana kinerja perusahaan-perusahaan yang bergerak di bidang otomotif tersebut dan prospeknya di masa yang akan datang, khususnya untuk membantu pengambilan keputusan investasi bagi kreditor dan investor potensial.

\section{B. TELAAH PUSTAKA}

\section{B.1 Signaling Theory}

Teori sinyal menjelaskan mengapa perusahaan memiliki dorongan untuk memberikan informasi laporan keuangan kepada pihak eksternal. Pihak eksternal yang dimaksud diantaranya investor, kreditor atau pengguna informasi lainnya. Perusahaan memberikan informasi laporan keuangan karena adanya asimetri informasi antara perusahaan dengan pihak eksternal. Kurangnya informasi pihak eksternal mengenai perusahaan menyebabkan mereka melindungi diri dengan memberikan harga rendah pada perusahaan yang bersangkutan. Pihak eksternal yang tidak memiliki informasi yang cukup juga akan menilai bahwa semua perusahaan memiliki nilai yang sama. Penilaian seperti ini tentunya akan merugikan bagi perusahaan yang memiliki kondisi lebih baik karena pihak eksternal akan menilai perusahaan lebih rendah dari yang seharusnya dan begitu pula sebaliknya. Oleh karena itu, perusahaan perlu memberikan sinyal kepada pihak eksternal yang dapat berupa informasi keuangan yang dapat dipercaya dan dapat mengurangi ketidakpastian mengenai prospek perusahaan di masa mendatang.

Pada penelitian ini perusahaan memberikan sinyal kepada pengguna laporan keuangan (investor) berupa informasi laba akuntansi, arus kas dan Net Profit Margin (NPM). Informasi ini sangat 
penting bagi para pengguna laporan keuangan sehingga pelaporan laba rugi dan laporan arus kas diharapkan dapat menimbulkan reaksi pasar. Reaksi pasar ditunjukkan dengan adanya perubahan harga saham perusahaan tertentu yang cukup signifikan pada saat pengumuman laporan keuangan. Angka akuntansi yang dilaporkan oleh perusahaan di dalam laporan keuangan dapat digunakan sebagai sinyal jika angka tersebut mencerminkan informasi mengenai kelengkapan kelengkapan keputusan perusahaan yang tidak dapat diamati. Angka tersebut pada saat perusahaan melaporkan komponen labanya kepada publik maka akan menjadi sebuah berita bagus karena dianggap perusahaan memberikan informasi yang lengkap mengenai perusahaan (Meythi, 2002).

Peningkatan laba akuntansi dapat mendorong investor untuk lebih tertarik dalam membeli saham perusahaan. Ketertarikan investor untuk membeli saham perusahaan akan dapat meningkatkan harga saham perusahaan dan berujung pada meningkatnya return saham perusahaan. Laba yang tinggi akan mendorong investor untuk membeli saham perusahaan yang bersangkutan karena tertarik akan laba investasi yang lebih tinggi. Dengan demikian, peningkatan pada laba akuntansi akan mendorong terjadinya peningkatan harga saham dan return saham perusahaan. Berdasarkan pada uraian mengenai pengaruh laba akuntansi terhadap return saham, maka dapat dirumuskan hipotesis dalam penelitian ini sebagai berikut:

$\mathbf{H}_{1}$ : Laba akuntasi berpengaruh signifikan terhadap return saham.

Arus kas merupakan salah satu indikator nilai pasar perusahaan. Artinya perusahaan yang mempunyai arus kas yang tinggi berarti mempunyai nilai pasar yang tinggi. Nilai pasar yang tinggi ini akan mendorong investor untuk tertarik berinvestasi pada saham perusahaan itu. Tentu saja ini akan meningkatkan harga saham perusahaan dan pada akhirnya berimbas pada meningkatnya return perusahaan. Dengan demikian dapat dikatakan bahwa peningkatan arus kas akan mendorong peningkatan pada return saham dan demikian pula sebaliknya. Berdasarkan pada uraian mengenai pengaruh total arus kas terhadap return saham, maka dapat dirumuskan hipotesis sebagai berikut:

$\mathbf{H}_{2}$ : Total arus kas berpengaruh signifikan terhadap return saham.

Salah satu indikator keberhasilan perusahaan adalah kemampuan mencetak laba secara efisien. Yaitu bahwa manajer perusahaan tersebut mampu membukukan pendapatan dan sales yang signifikan, dan dalam waktu yang sama manajer mampu meminimalisir biaya-biaya. Mengingat laba adalah selisih antara pendapatan dan biaya, maka ukuran efisiensi dapat dilihat dengan membandingkan (rasio) antara laba terhadap pendapatan. Rasio ini terkenal dengan sebutan NPM (Net Profit Margin) di mana tingginya NPM menyiratkan keahlian manajer dalam mencetak laba dengan meminimalisir biayabiaya. Investor di bursa seringkali mengkaitkan antara NPM terhadap return saham, di mana perusahaan dengan NPM yang tinggi dipersepsikan sebagai perusahaan yang memiliki prospek baik di masa datang. Berdasarkan pada uraian mengenai pengaruh Net Profit Margin (NPM) terhadap return saham, maka dapat dirumuskan hipotesis sebagai berikut:

$\mathbf{H}_{3}$ : Net Profit Margin (NPM) berpengaruh signifikan terhadap return saham.

\section{METODE PENELITIAN}

\section{C.1. Lokasi dan Desain Penelitian}

Penelitian ini dilakukan di Bursa Efek Indonesia. Dengan menganalisis apakah laba akuntansi, total arus kas dan Net Profit Margin berpengaruh Terhadap 
Return Saham. Penelitian ini menggunakan data panel (pooled data).

\section{C.2. Populasi dan Sampel}

Populasi dalam penelitian ini adalah perusahaan otomotif yang terdaftar di Bursa Efek Indonesia (BEI). Teknik pengambilan sampel menggunakan purposive sampling. Sampel dalam penelitian ini diambil dengan kriteria sampel sebagai berikut: Perusahaan otomotif yang listing di BEI dan mempublikasikan laporan keuangan selama empat tahun dari tahun 2013 sampai dengan 2016.

\section{C.3. Metode}

Metode pengumpulan data yang digunakan dalam bentuk file data atau data sekunder yang diperoleh dari laporan keuangan tahunan perusahaan yang terdaftar di Bursa Efek Indonesia dan tersedia di (http://www.idx.co.id) dan direktori pasar modal Indonesia (ICMD) pada 2013-2016.

\section{C.4. Analisis Data}

Penelitian ini menggunakan dua model untuk menguji pengaruh laba akuntansi, total arus kas dan net profit margin terhadap return saham pada perusahaan otomotif yang terdaftar di Bursa Efek Indonesia serta untuk melihat variabel mana yang mempunyai pengaruh paling besar terhadap return saham.

\section{HASIL DAN PEMBAHASAN}

\section{D.1. Deskripsi Variabel Penelitian}

Dalam penelitian ini mengambil sepuluh sampel perusahaan otomotif yang terdaftar pada Bursa Efek Indonesia yaitu Astra Otoparts, Indo Kordsa, Good year Indonesia, Astra Internasional, Indomobil Sukses Internasional, Indospring, Multi Prima Sejahtera, Multistrada Arah Sarana, dan Nipress. Pada sepuluh perusahaan tersebut masing-masing ada empat variabel yang diteliti yaitu laba akuntansi (X1), total arus kas (X2) dan Net Profit Margin (NPM) (X3) serta return saham (Y). Berikut ini adalah uraian perkembangan variabel penelitian selama periode penelitian tahun 2013 sampai dengan tahun 2016.

1. Astra Otoparts Tbk.

Tabel 1

(Dalam jutaan rupiah)

\begin{tabular}{|c|c|c|c|c|}
\hline Tahun & $\begin{array}{c}\text { Return } \\
\text { saham }\end{array}$ & $\begin{array}{c}\text { Laba } \\
\text { akuntansi }\end{array}$ & $\begin{array}{c}\text { Total arus } \\
\text { kas }\end{array}$ & $\begin{array}{c}\text { Net profit } \\
\text { margin }\end{array}$ \\
\hline 2013 & 0,088 & 1.135 .914 & 651.750 & 0,137 \\
\hline 2014 & $-0,013$ & 1.058 .015 & 2.337 .070 & 0,098 \\
\hline 2015 & 0,150 & 956.409 & 1.955 .570 & 0,078 \\
\hline 2016 & $-0,619$ & 322.701 & 2.033 .800 & 0,027 \\
\hline
\end{tabular}

Sumber: Diolah penulis, 2018

2. Indo Kordsa Tbk.

Tabel 2

(Dalam jutaan rupiah)

\begin{tabular}{|c|c|c|c|c|}
\hline Tahun & $\begin{array}{c}\text { Return } \\
\text { saham }\end{array}$ & $\begin{array}{c}\text { Laba } \\
\text { akuntansi }\end{array}$ & $\begin{array}{c}\text { Total arus } \\
\text { kas }\end{array}$ & $\begin{array}{c}\text { Net profit } \\
\text { margin }\end{array}$ \\
\hline 2013 & 0,395 & 300.290 .174 & 57.578 .037 & 0,129 \\
\hline 2014 & $-0,166$ & 73.813 .898 & 27.570 .330 & 0,027 \\
\hline 2015 & 1,222 & 211.585 .634 & 50.758 .709 & 0,076 \\
\hline 2016 & $-0,064$ & 167.473 .106 & 62.424 .000 & 0,060 \\
\hline
\end{tabular}

Sumber: Diolah penulis, 2018 
3. Goodyear Indonesia Tbk.

Tabel 3

(Dalam jutaan rupiah)

\begin{tabular}{|c|c|c|c|c|}
\hline Tahun & $\begin{array}{c}\text { Return } \\
\text { saham }\end{array}$ & $\begin{array}{c}\text { Laba } \\
\text { akuntansi }\end{array}$ & $\begin{array}{c}\text { Total arus } \\
\text { kas }\end{array}$ & $\begin{array}{c}\text { Net profit } \\
\text { margin }\end{array}$ \\
\hline 2013 & 0,250 & 6.673 .997 & 31.393 .509 & 0,032 \\
\hline 2014 & 0,520 & 61.725 .453 & 500.972 & 0,025 \\
\hline 2015 & 0,000 & 36.517 .448 & 388.387 & 0,017 \\
\hline 2016 & $-0,736$ & 1.478 .115 & 6.307 .225 & 0,001 \\
\hline
\end{tabular}

Sumber: Diolah penulis, 2018

4. Astra International Tbk.

Tabel 4

(Dalam jutaan rupiah)

\begin{tabular}{|c|c|c|c|c|}
\hline Tahun & $\begin{array}{c}\text { Return } \\
\text { saham }\end{array}$ & $\begin{array}{c}\text { Laba } \\
\text { akuntansi }\end{array}$ & $\begin{array}{c}\text { Total arus } \\
\text { kas }\end{array}$ & $\begin{array}{c}\text { Net profit } \\
\text { margin }\end{array}$ \\
\hline 2013 & 0,027 & 22.742 .000 & 20.200 .000 & 0,120 \\
\hline 2014 & $-0,074$ & 22.297 .000 & 71.900 .000 & 0,115 \\
\hline 2015 & 0,091 & 22.125 .000 & 28.400 .000 & 0,109 \\
\hline 2016 & $-0,191$ & 15.613 .000 & 47.200 .000 & 0,084 \\
\hline
\end{tabular}

Sumber: Diolah penulis, 2018

5. Indomobil Sukses Internasional Tbk.

Tabel 5

(Dalam jutaan rupiah)

\begin{tabular}{|c|c|c|c|c|}
\hline Tahun & $\begin{array}{c}\text { Return } \\
\text { saham }\end{array}$ & $\begin{array}{c}\text { Laba } \\
\text { akuntansi }\end{array}$ & Total arus kas & $\begin{array}{c}\text { Net profit } \\
\text { margin }\end{array}$ \\
\hline 2013 & $-0,585$ & 899.000 & 1.135 .008 & 0,045 \\
\hline 2014 & $-0,075$ & 621.139 & 1.121 .533 & 0,030 \\
\hline 2015 & $-0,183$ & 67.000 & 1.494 .130 & 0,003 \\
\hline 2016 & $-0,408$ & 22.000 & 2.136 .080 & 0,001 \\
\hline
\end{tabular}

Sumber: Diolah penulis, 2018

6. Indo Spring Tbk.

Tabel 6

(Dalam jutaan rupiah)

\begin{tabular}{|c|c|c|c|c|}
\hline Tahun & $\begin{array}{c}\text { Return } \\
\text { saham }\end{array}$ & $\begin{array}{c}\text { Laba } \\
\text { akuntansi }\end{array}$ & Total arus kas & $\begin{array}{c}\text { Net profit } \\
\text { margin }\end{array}$ \\
\hline 2013 & 0,200 & 134.068 & 1.505 .000 & 0,090 \\
\hline 2014 & $-0,363$ & 147.608 & 1.702 .000 & 0,086 \\
\hline 2015 & $-0,401$ & 127.657 & 2.133 .000 & 0,068 \\
\hline 2016 & $-0,781$ & 1.934 & 1.826 .000 & 0,000 \\
\hline
\end{tabular}

Sumber: Diolah penulis, 2018 
7. Multi Prima Sejahtera Tbk.

Tabel 7

(Dalam jutaan rupiah)

\begin{tabular}{|c|c|c|c|c|}
\hline Tahun & $\begin{array}{c}\text { Return } \\
\text { saham }\end{array}$ & $\begin{array}{c}\text { Laba } \\
\text { akuntansi }\end{array}$ & Total arus kas & $\begin{array}{c}\text { Net profit } \\
\text { margin }\end{array}$ \\
\hline 2013 & 2,200 & 16.600 & 49.136 & 0,241 \\
\hline 2014 & $-0,490$ & 8.555 & 51.901 & 0,110 \\
\hline 2015 & 0,350 & 4.130 & 7.817 & 0,062 \\
\hline 2016 & $-0,133$ & 18.173 & 56.031 & 0,233 \\
\hline
\end{tabular}

Sumber: Diolah penulis, 2018

8. Multistrada Arah Sarana Tbk.

Tabel 8

(Dalam jutaan rupiah)

\begin{tabular}{|c|c|c|c|c|}
\hline Tahun & $\begin{array}{c}\text { Return } \\
\text { saham }\end{array}$ & $\begin{array}{c}\text { Laba } \\
\text { akuntansi }\end{array}$ & Total arus kas & $\begin{array}{c}\text { Net profit } \\
\text { margin }\end{array}$ \\
\hline 2013 & $-0,100$ & 4.262 & 2.863 .585 & 0,001 \\
\hline 2014 & $-0,133$ & 47.961 & 462.579 & 0,011 \\
\hline 2015 & 0,076 & 6.299 & 573.726 & 0,001 \\
\hline 2016 & $-0,166$ & 357.735 & 510.848 & 0,113 \\
\hline
\end{tabular}

Sumber: Diolah penulis, 2018

9. Nipress Tbk.

Tabel 9

(Dalam jutaan rupiah)

\begin{tabular}{|c|c|c|c|c|}
\hline Tahun & $\begin{array}{c}\text { Return } \\
\text { saham }\end{array}$ & $\begin{array}{c}\text { Laba } \\
\text { akuntansi }\end{array}$ & Total arus kas & $\begin{array}{c}\text { Net profit } \\
\text { margin }\end{array}$ \\
\hline 2013 & $-0,034$ & 21.553 & 7.305 & 0,030 \\
\hline 2014 & $-0,298$ & 33.782 & 290.328 & 0,037 \\
\hline 2015 & $-0,849$ & 50.135 & 33.054 & 0,049 \\
\hline 2016 & $-0,127$ & 30.671 & 39.828 & 0,031 \\
\hline
\end{tabular}

Sumber: Diolah penulis, 2018

10. Selamat Sempurna Tbk.

Tabel 10

(Dalam jutaan rupiah)

\begin{tabular}{|c|c|c|c|c|}
\hline Tahun & $\begin{array}{c}\text { Return } \\
\text { saham }\end{array}$ & $\begin{array}{c}\text { Laba } \\
\text { akuntansi }\end{array}$ & Total arus kas & $\begin{array}{c}\text { Net profit } \\
\text { margin }\end{array}$ \\
\hline 2013 & 0,856 & 269.000 & 59.381 & 0,124 \\
\hline 2014 & 0,366 & 338.000 & 93.398 & 0,142 \\
\hline 2015 & 0,376 & 420.000 & 75.860 & 0,159 \\
\hline 2016 & 0,002 & 461.000 & 122.963 & 0,164 \\
\hline
\end{tabular}

Sumber: Diolah penulis, 2018

\section{D.2 Analisis Statistik Deskriptif}

Pengujian statistik deskriptif dilakukan untuk memberikan penjelasan mengenai nilai maksimum nilai minimum, nilai rata-rata (mean), dan standar deviasi dari masing-masing variabel. Pengukuran nilai rata-rata merupakan cara yang paling umum digunakan untuk pengukuran sentral dari suatu distribusi data. Standar deviasi digunakan untuk 
mengukur seberapa luas atau seberapa jauh penyimpangan data dari nilai rata-ratanya, hasil pengujian yang telah dilakukan dapat dilihat pada tabel di bawah ini:

Tabel 11

Uji Statistik Deskripsif

\begin{tabular}{|c|c|c|c|c|c|}
\hline \multicolumn{6}{|c|}{ Statistics } \\
\hline & & $\begin{array}{c}\text { LOG_LABA } \\
\text { AKUNTANSI }\end{array}$ & $\begin{array}{c}\text { LOG_TOTAL } \\
\text { ARUS KAS }\end{array}$ & $\begin{array}{c}\text { NET PROFIT } \\
\text { MARGIN }\end{array}$ & $\begin{array}{l}\text { RETURN } \\
\text { SAHAM }\end{array}$ \\
\hline \multirow[t]{2}{*}{$\mathrm{N}$} & Valid & 40 & 40 & 40 & 40 \\
\hline & Missing & 0 & 0 & 0 & 0 \\
\hline \multicolumn{2}{|c|}{ Mean } & 5.6913 & 5.9804 & .07430 & .00140 \\
\hline \multicolumn{2}{|c|}{ Median } & 5.5412 & 6.1147 & .06500 & -.04900 \\
\hline \multicolumn{2}{|c|}{ Std. Deviation } & 1.44785 & 1.11350 & .061685 & .549005 \\
\hline \multicolumn{2}{|c|}{ Minimum } & 3.29 & 3.86 & .001 & -.849 \\
\hline \multicolumn{2}{|c|}{ Maximum } & 8.48 & 7.80 & .241 & 2.200 \\
\hline
\end{tabular}

Sumber : Output SPSS, 2018

Pada tabel di atas dapat dilihat bahwa variabel laba akuntansi dengan pengamatan selama periode 2013-2016 terlihat bahwa nilai rataratanya sebesar 5,6913 dan standar deviasinya (tingkat sebaran datanya) sebesar 1,44785 artinya terjadi penyimpangan nilai laba akuntansi sebesar 1,44785. Selain itu, laba akuntansi memiliki nilai terendah sebesar 3,29 yang dimiliki oleh PT. Indospring periode tahun 2016 dan nilai tertinggi sebesar 8,48 yang dimiliki oleh PT. Indo Kordsa periode 2013.

Pada variabel total arus kas terlihat bahwa nilai rata-ratanya sebesar 5,9804 dan standar deviasinya sebesar 1,11350 artinya terjadi penyimpangan nilai total arus kas sebesar 1,11350. Selain itu, total arus kas memiliki nilai terendah sebesar 3,86 yang dimiliki oleh PT. Nipress periode tahun 2013 dan nilai tertinggi sebesar 7,80 yang dimiliki oleh PT. Indo Kordsa periode 2016.

Sedangkan pada variabel net profit margin terlihat bahwa nilai rata-ratanya sebesar 0,07430 dan standar deviasinya sebesar 0,061685 artinya terjadi penyimpangan nilai net profit margin sebesar 0,061685. Selain itu, net profit margin memiliki nilai terendah sebesar 0,001 yang dimiliki oleh PT. Multistrada Arah Sarana periode 2013 dan 2015, PT. Goodyear Indonesia periode 2016, PT. Indomobil Sukses periode 2016 dan PT. Indospring periode 2016. Sedangkan nilai tertinggi sebesar 0,241 yang dimiliki oleh PT. Multi Prima Sejahtera periode 2013.

Pada variabel return saham terlihat bahwa nilai rata-ratanya sebesar 0,00140 dan standar deviasinya sebesar 0,549005 artinya terjadi penyimpangan nilai return saham sebesar 0,549005. Selain itu return saham memiliki nilai terendah sebesar -0,849 yang dimiliki oleh PT. Nipress periode tahun 2015 dan nilai tertinggi sebesar 2,200 yang dimiliki oleh PT. Multi Prima Sejahtera periode 2013 
Tabel 12

Uji Multikolinieritas

\begin{tabular}{|c|c|c|c|c|c|c|c|}
\hline \multicolumn{8}{|c|}{ Coefficientsa } \\
\hline \multirow[b]{2}{*}{ Model } & \multicolumn{2}{|c|}{$\begin{array}{c}\text { Unstandardized } \\
\text { Coefficients }\end{array}$} & \multirow{2}{*}{$\begin{array}{c}\begin{array}{c}\text { Standardiz } \\
\text { ed } \\
\text { Coefficients }\end{array} \\
\text { Beta }\end{array}$} & \multirow[b]{2}{*}{$\mathrm{T}$} & \multirow[b]{2}{*}{ Sig. } & \multicolumn{2}{|c|}{$\begin{array}{l}\text { Collinearity } \\
\text { Statistics }\end{array}$} \\
\hline & B & $\begin{array}{l}\text { Std. } \\
\text { Error }\end{array}$ & & & & Tolerance & VIF \\
\hline (Constant) & -.403 & .452 & & -.891 & .379 & & \\
\hline LABA AKT & .107 & .075 & .281 & 1.422 & .164 & .487 & 2.055 \\
\hline ARUS KAS & -.085 & .099 & -.173 & -.858 & .397 & .468 & 2.135 \\
\hline $\begin{array}{l}\text { NET PROFIT } \\
\text { MARGIN }\end{array}$ & 4.142 & 1.323 & .465 & 3.132 & .003 & .861 & 1.161 \\
\hline
\end{tabular}

Dependent Variable: RETURN SAHAM

Sumber: Output SPSS, 2018

Berdasarkan tabel di atas maka dapat disimpulkan bahwa nilai variance inflation vactor (VIF) laba akuntansi, total arus kas, dan net profit margin masing masing 2,055, 2,135, dan 1,161 adalah kurang dari 10 maka tidak terjadi multikolinieritas.

Tabel 13

Uji F

\begin{tabular}{|c|c|c|c|c|c|c|}
\hline \multicolumn{7}{|c|}{ ANOVAa } \\
\hline \multicolumn{2}{|l|}{ Model } & $\begin{array}{c}\text { Sum of } \\
\text { Squares }\end{array}$ & Df & $\begin{array}{c}\text { Mean } \\
\text { Square }\end{array}$ & $\mathrm{F}$ & Sig. \\
\hline \multirow[t]{3}{*}{1} & Regression & 3.706 & 3 & 1.235 & 5.525 & $.003^{\mathrm{b}}$ \\
\hline & Residual & 8.049 & 36 & .224 & & \\
\hline & Total & 11.755 & 39 & & & \\
\hline \multicolumn{7}{|c|}{ a. Dependent Variable: RETURN SAHAM } \\
\hline \multicolumn{7}{|c|}{ b. Predictors: (Constant), NET PROFIT MARGIN, LABA AKT, ARUS KAS } \\
\hline
\end{tabular}

Sumber: Output SPSS, 2018

\section{Tabel 14}

Uji T

\begin{tabular}{|c|c|c|c|c|c|c|}
\hline \multicolumn{7}{|c|}{ Coefficients ${ }^{a}$} \\
\hline & & \multicolumn{2}{|c|}{$\begin{array}{c}\text { Unstandardized } \\
\text { Coefficients }\end{array}$} & \multirow{2}{*}{$\begin{array}{c}\text { Standardized } \\
\text { Coefficients } \\
\text { Beta }\end{array}$} & \multirow[b]{2}{*}{$\mathrm{T}$} & \multirow[b]{2}{*}{ Sig. } \\
\hline \multicolumn{2}{|c|}{ Model } & $\mathrm{B}$ & Std. Error & & & \\
\hline \multirow[t]{4}{*}{1} & (Constant) & -.403 & .452 & & -.891 & .379 \\
\hline & LABA AKT & .107 & .075 & .281 & 1.422 & .164 \\
\hline & ARUS KAS & -.085 & .099 & -.173 & -.858 & .397 \\
\hline & NET PROFIT MARGIN & 4.142 & 1.323 & .465 & 3.132 & .003 \\
\hline
\end{tabular}

Sumber: Output SPSS, 2018

Laba akuntansi, diketahui nilai sig. $0,164>0,05$ maka secara parsial variabel laba akuntansi (X1) tidak berpengaruh terhadap variabel return saham (Y). Total arus kas, diketahui nilai sig. 0,397>0,05 maka secara parsial variabel total arus kas (X2) tidak berpengaruh terhadap variabel return saham (Y). Net profit margin diketahui nilai sig. $0,003<0,05$ maka secara parsial variabel net profit margin (X2) berpengaruh terhadap variabel return saham

(Y). 
Tabel 15

Uji Determinasi

\begin{tabular}{|l|r|r|r|r|}
\hline \multicolumn{5}{|c|}{ Model Summary } \\
\hline Model & $\mathrm{R}$ & R Square & $\begin{array}{c}\text { Adjusted R } \\
\text { Square }\end{array}$ & $\begin{array}{c}\text { Std. Error of the } \\
\text { Estimate }\end{array}$ \\
\hline 1 & $.561^{\mathrm{a}}$ & .315 & .258 & .472851 \\
\hline $\begin{array}{l}\text { Predictors: (Constant), NET PROFIT MARGIN, LABA AKT, ARUS KAS } \\
\text { Dependent Variable: RETURN SAHAM } \\
\text { Sumber: Output SPSS, 2018 }\end{array}$ \\
\hline
\end{tabular}

Dari hasil estimasi diperoleh nilai $\mathrm{R}^{2}$ sebesar 0,315 yang artinya $31,5 \%$ variasi dalam variabel dependen (return saham) dapat dijelaskan oleh variabel independen yang dimasukkan dalam model laba akuntansi (X1), total arus kas (X2), dan net profit margin (X3). Sedangkan sisanya sebesar $68,5 \%$ dipengaruhi oleh variabel yang tidak dijelaskan dalam model atau selain tiga variabel tersebut.

Tabel 16

Hasil Analisis Regresi

\begin{tabular}{|c|c|c|c|}
\hline $\begin{array}{c}\text { NO } \\
.\end{array}$ & Variabel Independen & Sig. & Keterangan \\
\hline 1. & Laba Akuntansi & 0,164 & Tidak berpengaruh, 0,164 $>0,05$ \\
\hline 2. & Total Arus Kas & 0,397 & Tidak berpengaruh, 0,397 $>0,05$ \\
\hline 3. & Net Profit Margin & 0,003 & Berpengaruh, 0,003 $<0,05$ \\
\hline
\end{tabular}

Sumber: Output SPSS, 2018

Tabel 17

Urutan Nilai Koefisien Beta

\begin{tabular}{|c|c|c|}
\hline Variabel bebas & $\begin{array}{c}\text { Koefisien regresi } \\
\text { standar }\end{array}$ & $\begin{array}{c}\text { Urutan } \\
\text { kontribusi }\end{array}$ \\
\hline Laba akuntansi & 0,281 & Kedua \\
\hline Total arus kas & $-0,173$ & Ketiga \\
\hline Net profit margin & 0,465 & Pertama \\
\hline
\end{tabular}

Sumber: Output SPSS, 2018

Berdasarkan pada tabel di atas menunjukkan bahwa variabel Net Profit Margin memberikan kontribusi yang paling besar terhadap return saham yang ditunjukkan dengan nilai koefisien standar yang paling besar yaitu 0,465 disusul oleh laba akuntansi sebesar 0,281 dan kemudian yang terakhir adalah total arus kas sebesar -0,173.

\section{D.4 Pembahasan}

Tujuan utama penelitian ini adalah untuk memperoleh bukti empiris mengenai adanya pengaruh laba akuntansi, total arus kas dan net profit margin terhadap return saham pada perusahaan otomotif yang terdaftar pada Bursa Efek Indonesia, dari hasil pengujian regresi berganda, dapat dibuktikan bahwa variabel independen yaitu laba akuntansi, total arus kas dan net profit margin secara bersama sama (simultan) signifikan terhadap return saham dengan hasil signifikansi uji $\mathrm{F}$ 0,003 lebih kecil dari 0,05 .

Namun dari hasil pengujian secara parsial menunjukkan bahwa laba akuntansi tidak terbukti mempengaruhi return saham terlihat dari nilai signifikansi uji $\mathrm{T}$ 0,164 lebih besar dari 0,05. Hal ini karena adanya peristiwa transitori (transitory events) dalam akuntansi, peristiwa transitori adalah pendapatan yang sudah diterima kas nya akan tetapi belum menjadi hak perusahaan dan biaya yang 
sudah dibayar dengan kas akan tetapi belum menjadi kewajiban perusahaan di mana konsep ini banyak diterapkan pada industri yang secara khusus mengakibatkan angka laba (rugi) yang dilaporkan dalam laporan laba-rugi berfluktuasi (naik turun). Laba akuntansi memiliki beberapa keunggulan dan kelemahan. Keunggulan laba akuntansi adalah masih bermanfaat untuk membantu pengambilan keputusan ekonomi, dapat diuji kebenarannya karena didasarkan pada transaksi atau fakta aktual yang didukung bukti objektif. Laba akuntansi memenuhi kriteria konservatisme yang artinya tidak mengakui perubahan nilai tetapi hanya mengakui laba yang direalisasi. Namun, kelemahan laba akuntansi adalah gagal mengakui kenaikan nilai aktiva yang belum direalisasi dalam satu periode karena prinsip biaya historis dan prinsip realisasi yang konservatisme di mana laba akuntansi hanya mengakui untung yang direalisasikan (Ferry dan Wati, 2004).

Dari hasil pengujian secara parsial total arus kas juga tidak mempengaruhi return saham, penelitian ini didukung oleh penelitian yg dilakukan oleh Nur Aini (2009) dengan hasil penelitian bahwa total arus kas tidak mempengaruhi return saham, dengan hasil tersebut maka dapat dimaknai bahwa investor mempunyai anggapan total arus kas tidak memiliki kandungan informasi untuk menjadi tolak ukur untuk memprediksi return saham. Arus kas dari aktivitas operasi merupakan cerminan kemampuan perusahaan dalam menghasilkan kas dan setara kas yang cukup untuk melunasi pinjaman, memelihara kemampuan operasi perusahaan, membayar dividen dan melakukan investasi baru tanpa mengandalkan sumber pendanaan dari luar (PSAK No 2 paragraf 12 revisi tahun 2009). Total arus kas tidak digunakan oleh pelaku pasar/investor sebagai alat pertimbangan keputusan investasi.
Hasil penelitian ini tidak sejalan dengan penelitian yang dilakukan oleh Latief (2014) yang menunjukkan hasil bahwa arus kas operasi berpengaruh terhadap return saham. Secara teori, semakin tinggi arus kas operasi perusahaan maka semakin tinggi kepercayaan investor terhadap perusahaan karena perusahaan dianggap mampu menghasilkan arus kas masuk yang baik untuk kegiatan operasionalnya. Hal ini pada akhirnya akan meningkatkan return sahamnya.

Sedangkan net profit margin dalam pengujian secara parsial disimpulkan bahwa net profit margin berpengaruh secara parsial terhadap return saham. Penelitian ini mendukung penelitian yang dilakukan Astuti (2013) yang menyatakan bahwa semakin tinggi rasio net profit margin berarti laba yang dihasilkan perusahaan tersebut juga semakin besar maka akan menarik minat para investor untuk melakukan transaksi dengan perusahaan yang bersangkutan. Menurut Nathaniel (2008), net profit margin melaporkan kemampuan perusahaan menghasilkan laba dari tingkat penjualan tertentu. Rasio ini menginterpretasikan tingkat efisiensi perusahaan yakni sejauh mana kemampuan perusahaan menekan biaya-biaya yang ada di perusahaan pada periode tertentu. Selain itu, menurut Bastian dan Suhardjono (2006), net profit margin adalah perbandingan antara laba bersih dengan penjualan bersih. Semakin besar net profit margin menunjukkan kinerja perusahaan yang produktif untuk memperoleh laba yang tinggi melalui tingkat penjualan tertentu serta kemampuan perusahaan yang baik dalam menekan biaya-biaya operasionalnya. Hal ini meningkatkan kepercayaan investor untuk menanamkan modalnya pada perusahaan tersebut sehingga permintaan akan saham perusahaan tersebut meningkat yang otomatis diikuti dengan naiknya harga saham tersebut. Dari penjelasan di atas maka semakin 
mendukung penelitian ini bahwa net profit margin adalah variabel yang paling berpengaruh terhadap return saham dibandingkan dengan variabel lainnya yaitu laba akuntansi dan total arus kas.

\section{E. PENUTUP}

Berdasarkan hasil analisis dan pembahasan, maka dapat ditarik kesimpulan bahwa laba akuntansi tidak mempunyai pengaruh signifikan terhadap return saham. Hal ini karena adanya peristiwa transitori dalam akuntansi yaitu pendapatan yang sudah diterima kasnya akan tetapi belum menjadi hak perusahaan di mana konsep ini banyak diterapkan pada industri yang secara khusus mengakibatkan angka laba (rugi) yang dilaporkan dalam laporan laba-rugi berfluktuasi.

Total arus kas tidak berpengaruh signifikan terhadap return saham dapat dimaknai bahwa investor mempunyai anggapan total arus kas tidak memiliki kandungan informasi untuk menjadi tolak ukur untuk memprediksi return saham. Arus kas dari aktivitas operasi merupakan cerminan kemampuan perusahaan dalam menghasilkan kas dan setara kas yang cukup untuk melunasi pinjaman, memelihara kemampuan operasi perusahaan, membayar dividen dan melakukan investasi baru tanpa mengandalkan sumber pendanaan dari luar.

Net profit margin mempunyai pengaruh signifikan terhadap return saham. Semakin besar net profit margin menunjukkan kinerja perusahaan yang produktif untuk memperoleh laba yang tinggi melalui tingkat penjualan tertentu serta kemampuan perusahaan yang baik dalam menekan biaya-biaya operasionalnya. Hal ini meningkatkan kepercayaan investor untuk menanamkan modalnya pada perusahaan tersebut sehingga permintaan akan saham perusahaan tersebut meningkat yang otomatis diikuti dengan naiknya harga saham tersebut.

Net Profit Margin mempunyai pengaruh yang paling dominan terhadap variabel return saham dibandingkan dengan variabelvariabel bebas lainnya yang mempengaruhi return saham. Hal ini terjadi karena variabel laba akuntansi dan total arus kas masih memiliki kelemahan untuk dijadikan sebagai tolak ukur return saham, seperti laba akuntansi yang kadang mengalami peristiwa transitory dan total arus kas tidak memiliki cukup informasi untuk menentukan return saham dan hanya sedikit pelaku pasar/investor yang menggunakan total arus kas sebagai alat pertimbangan keputusan investasi.

Secara akademis, penelitian ini diharapkan dapat menggeneralisasi hasil penelitian berkaitan dengan faktor-faktor yang mempengaruhi return saham, dengan beberapa perbaikan diantaranya adalah emiten (perusahaan) yang dijadikan sampel adalah perusahaanperusahaan yang tidak hanya terdaftar sebagai emiten otomotif saja tetapi juga pada emiten lainnya pada berbagai sektor usaha. Selain itu, penelitian ini juga dapat dikembangkan dengan memperpanjang periode penelitian dan memperbanyak variabel yang diteliti. Secara manajerial, perusahaan harus memberikan penekanan pada faktor-faktor lain yang kemungkinan besar.

\section{DAFTAR PUSTAKA}

Ball, Ray and Brown, Philip. 1968. An Empirical Evaluation of Accounting Income Number. Journal of Accounting Research.

Ferry dan Erni Eka Wati. 2004. Pengaruh Informasi Laba, Aliran Kas, dan Komponen Aliran Kas terhadap Harga Saham pada Perusahaan Manufaktur di Indonesia. Simposium Nasional 
Pengaruh Laba Akuntansi, Total Arus Kas, ... Linda \& Rahmi

Akuntansi VII. Desember 2004.

Hanafi. M. M. 2014. Manajemen Keuangan. Edisi Pertama. BPFE. Yogyakarta.

Hendriksen, E. (1997). Accounting Theory, 4th edition. Jakarta: Erlangga.

Hartono, S. d. 2012. Pengaruh Informasi Laba Dan Arus Kas Terhadap Harga Saham. Jurnal Ilmiah Akuntansi No.7.

Indra Bastian dan Suhardjono. 2006. Akuntansi Perbankan.Edisi 1. Jakarta: Salemba Empat.

Latief, W. F. 2014. Pengaruh Komponen Arus Kas, Laba Akuntansi dan Dividend Yield Terhadap Return Saham. Semarang: Universitas Diponegoro.

Meythi. 2002. Pengaruh Arus Kas Operasi Terhadap Harga Saham Dengan Persistensi Laba Sebagai Variabel Intervening. Bandung: Universitas Maranatha.
Nicky Nathaniel. 2008. Analisis Faktor-Faktor yang Mempengaruhi Return Saham (Studi Pada Saham Real estate dan properti di Bursa Efek Indonesia Periode 20032006). Tesis. Diterbitkan Magister Manajemen Program Pascasarjana Universitas Diponegoro.

Nur Aini. 2009. Pengaruh Laba dan Komponen Arus Kas Terhadap Return Saham. Jurnal Telaah Manajemen (TEMA) 6, Edisi 2. Sept 2009.

Rahmawati. 2005. Relevansi Nilai Earning Dengan Pendekatan Terintegrasi : Hubungan Nonlinier. Jurnal Akuntansi \& Auditing Vol. 9.

Thiono, Handri. 2006. Perbandingan Keakuratan Model Arus Kas Metode Langsung dan Tidak Langsung Dalam Memprediksi Arus Kas dan Deviden Masa Depan. SIMPOSIUM NASIONAL AKUNTANSI, IX: 1 - 21.

www.idx.co.id 